Volume 2 Issue 1, March 2018: pp. 335-353. Copyright (c) 2017 HOLREV. Faculty of Law, Halu Oleo University, Kendari, Southeast Sulawesi, Indonesia. ISSN: 2548-1762 I e-ISSN: 2548-1754. Open Access at: http://ojs.uho.ac.id/index.php/holrev/

Halu Oleo Law Review is licensed under a Creative Commons Attribution 4.0 International License, which permits unrestricted use, distribution, and reproduction in any medium, provided the original work is properly cited.

\title{
Perlindungan Hukum Hak Kekayaan Intelektual Masyarakat Kota Baubau
}

\author{
Legal Protection of Property Rights of Baubau Citizen \\ Haris Yusuf \\ Dosen Hukum Perdata Fakultas Hukum Universitas Halu Oleo \\ E-mail: harisyusuf24@gmail.com \\ Rahman Hasima \\ Dosen Hukum Bisnis Fakultas Hukum Universitas Halu Oleo \\ E-mail: rahmanhasima07@gmail.com
}

\begin{abstract}
This research analyzed the condition of protection for property rights and the model of legal development protection on Baubau Citizen. The method applied is juridical and empirical research by means of statute, comparative, and historical approach and analyzed qualitative description. This study revealed that Baubau Citizen have a great awareness to protect their property rights due to having various cultures and craft industries survived and developed in facing a free market and modernization. Yet, they couldn't acquire the property rights which caused by some obstacles that are firstly, lack of knowledge even local government unable to understand that began from the scope, registration process, and value taken from property rights. Secondly, relatively either low incentive or governmental reward on citizen invention caused craftsman, invertor and researcher who created innovations. Thirdly, insufficient information of property rights due to long distance of handmade inventor including central information. Meanwhile, the development for protection of property rights of Baubau Citizen covered as follow; 1) Legal umbrella for local ordinance dealt with Property Rigths, 2) Property Rights Documents of Baubau Citizen, 3) Taking a part of Local Government in order to keep and encourage inventor in Property Rights, 4) Constructing legal capacity building through seminar and culture workshop, 5) Training of documentation and registration of Property Rights.
\end{abstract}

Keyword: property rights, legal protection, Baubau citizen.

Abstrak: Artikel ini mengkaji tentang kondisi perlindungan hak kekayaan intelektual masyarakat Kota Baubau dan model pengembangan perlindungan hukum hak kekayaan intelektual masyarakat Kota Baubau. Tipe penelitian yang digunakan adalah yuridis empiris dengan menggunakan pendekatan perundangundangan (statute approach), pendekatan perbandingan (comparative approach) 
dan pendekatan historis (historical approach) dan menggunakan analisis deskriptif kualitatif. Berdasarkan hasil penelitian disimpulkan bahwa Kota Baubau mempunyai potensi yang sangat besar dalam perlindungan HKI karena memiliki keanekaragaman budaya dan hasil- hasil industri kreatif yang mampu hidup dan berkembang dalam menghadapi era perdagangan bebas dan modernisasi yang terjadi saat ini. Namun belum ada yang mendapatkan perlindungan HKI karena terdapat beberapa kendala, di antaranya pertama, masih rendahnya tingkat pengetahuan masyarakat bahkan pemerintah tentang hak kekayaan intelektual itu sendiri, mulai dari ruang lingkup, proses pendaftaran, dan manfaat apa yang diperoleh dari adanya perolehan hak dari kekayaan intelektual. Kedua, relatif masih rendahnya insentif atau penghargaan pemerintah atas karya cipta masyarakat hingga pada akhirnya kurang memicu para seniman, peneliti ataupun penemu untuk menghasilkan karya yang inovatif. Ketiga, kurangnya informasi tentang HKI yang disebabkan oleh jauhnya jarak letak tempat penemu/pengrajin terhadap pusatpusat informasi HKI. Sedangkan Model pengembangan perlindungan Hak kekayaan intelektual masyarakat kota Baubau dapat meliputi : 1)Pembentukan payung hukum berupa perda yang mengatur Hak Kekayaan Intelektual, 2) Pendokumentasian HKI masyarakat Kota Baubau, 3) Peran aktif pihak terkait/pemerintah untuk melindungi dan menumbuhkan kesadaran kepada pengrajin/penemu/seniman akan pentingnya HKI, 4) Membangun budaya hukum bagi masyarakat melalui seminar-seminar atau lokakarya budaya, 5) Pelatihan pencatatan dan pendaftaran HKI.

Kata kunci: Hak Kekayaan Intelektual, Perlindungan Hukum, Masyarakat Kota Baubau

\section{PENDAHULUAN}

Masyarakat negara berkembang di dunia merupakan masyarakat transformasi dari masyarakat tradisional ke masyarakat industri. Ketika globalisasi, pembangunan dan budaya barat kemudian menjadi paradigma yang dipakai dalam pembangunan ekonomi negara berkembang seperti Indonesia, sistem hukum dan ekonomi negara bersangkutan tentunya mengimbas baik langsung maupun tidak langsung kepada kehidupan masyarakat. Salah satunya Hak Kekayaan Intelektual disingkat "HKI" atau akronim "HaKI", padanan kata yang biasa digunakan untuk Intellectual Property Rights (IPR), yang merupakan sistem pengakuan dan perlindungan terhadap karya cipta dan penemuan yang timbul atau dilahirkan oleh manusia yang di dalamnya terdapat item-item yang terdiri dari hak cipta, merek dan indikasi geografis, desain industri, paten, desain tata letak sirkuit terpadu, rahasia dagang, dan perlindungan varietas tanaman. Hal ini menjadi trend yang kemudian dipakai oleh masyarakat untuk lebih melindungi dan mengikat hak atas karya intelektualnya.

HKI terkait dengan kreativitas manusia, dan daya cipta manusia dalam memenuhi kebutuhan atau memecahkan masalah kehidupannya, baik dalam seni, ilmu pengetahuan 
dan teknologi maupun produk unggulan suatu masyarakat. Oleh karena itu, pengembangan ilmu pengetahuan dan teknologi disertai dengan eksistensi HKI sangat penting. Yang mana kegiatan penelitian ini tidak dapat menghindar dari masalah HKI apabila menginginkan suatu penghormatan hak maupun inovasi baru, dan orisinalitasnya.

Permasalahan mengenai Hak Kekayaan Intelektual akan menyentuh berbagai aspek seperti aspek teknologi, industri, sosial, budaya, dan berbagai aspek lainnya. Akan tetapi, aspek terpenting jika dihubungkan dengan upaya perlindungan bagi karya intelektual adalah aspek hukum. Hukum diharapkan mampu mengatasi berbagai permasalahan yang timbul berkaitan dengan Hak Kekayaan Intelektual tersebut. Hukum harus dapat memberikan perlindungan bagi karya intelektual, sehingga mampu mengembangkan daya kreasi masyarakat yang akhirnya bermuara pada tujuan berhasilnya perlindungan Hak Kekayaan Intelektual. ${ }^{1}$

Aspek teknologi juga merupakan faktor yang sangat dominan dalam perkembangan dan perlindungan Hak Kekayaan Intelektual. Perkembangan teknologi informasi yang sangat cepat saat ini telah menyebabkan dunia terasa semakin sempit, informasi dapat dengan mudah dan cepat tersebar ke seluruh pelosok dunia. Pada keadaan seperti ini Hak Kekayaan Intelektual menjadi semakin penting. Hal ini disebabkan Hak Kekayaan Intelektual merupakan hak monopoli yang dapat digunakan untuk melindungi investasi dan dapat dialihkan haknya.

Salah satu isu yang menarik dan saat ini tengah berkembang dalam lingkup kajian hak kekayaan intelektual (HKI) adalah perlindungan hukum terhadap kekayaan intelektual yang dihasilkan oleh masyarakat asli atau masyarakat tradisional. Kekayaan intelektual yang dihasilkan oleh masyarakat asli tradisional ini mencakup banyak hal mulai dari sistem pengetahuan tradisional ini mencakup banyak hal mulai dari sistem

1 Signifikansi hukum yang berkenan dengan HAKI, searah dengan perlunya perlindungan hukum terhadap temuan-temuan hasil karya cipta putra Indonesia. Serta perlunya pemerintah khususnya pemerintah Provinsi dan Kab/Kota dan Perguruan Tinggi memfasilitasi para pencipta dan pengrajin untuk dapat mendaftarkan karya -karya mereka. Dengan dilandasi oleh pemikiran-pemikiran tidak semua orang mempunyai kemampuan, talenta, waktu untuk menemukan sesuatu yang baru di bidang ilmu pengetahuan, teknologi, bioteknologi Apabila tidak ada perlindungan hukum atas temuan-temuan di bidang ilmu pengetahuan, teknologi, bioteknologi. Maka setiap orang dapat memproduksi tanpa batas sehingga penemu dari temuan tersebut tidak mendapatkan nilai ekonomis. Bahkan akan merugikan penemu dan menjadikan setiap orang tidak kompetitif. Terkait dengan hal ini, lihat Jabalnur, "Perlindungan Hak Paten bagi Pengrajin Khas", Halu Oleo Law Review (HOLREV), Vol. 1, Issue 2, September 2017, http://ojs.uho.ac.id/index.php/holrev/article/view/3646/3139, diakses pada tanggal 13 Januari 2018, hlm. 282. 
pengetahuan tradisional (traditional knowledge), karya-karya seni, hingga apa yang dikenal sebagai indigenous science and technology.

Sebagai salah satu isu penting yang berkaitan dengan hak kekayaan intelektual dewasa ini adalah sejauh mana pengetahuan tradisional (traditional knowledge) khususnya kesenian tradisional (folklor) dan industri masyarakat Baubau mendapat perlindungan. Karena peliknya masalah ini dan mengingat begitu pentingnya perlindungan terhadap aset-aset budaya masyarakat Baubau terutama mengenai kesenian tradisional, adat istiadat, dan perkembangan industri lainnya, maka tim peneliti menganalisis secara mendalam dan hati-hati mengenai perlindungan hukum hak kekayaan intelektual adat masyarakat kota Baubau, yang hasilnya peneliti tuangkan dalam bentuk dokumen.

Berdasarkan penjelasan di atas maka yang menjadi permasalahan dalam penelitian ini adalah sebagai berikut:

1. Bagaimana kondisi Hak Kekayaan Intelektual (HKI) dari masyarakat Kota Baubau?

2. Bagaimana model pengembangan perlindungan hukum hak kekayaan intelektual masyarakat kota Baubau?

\section{METODE PENELITIAN}

\section{Tipe Penelitian}

Tipe penelitian yang digunakan dalam penelitian ini adalah yuridis empiris. Penelitian yuridis empiris adalah penelitian hukum mengenai pemberlakuan atau implementasi ketentuan hukum normatif secara in action pada setiap peristiwa hukum tertentu yang terjadi dalam masyarakat.

\section{Pendekatan Penelitian}

Dalam penelitian ini akan menganalisis secara yuridis melalui 3 (tiga) pendekatan²:

1) Pendekatan Perundang-undangan (statute-approach), yaitu penelitian hukum yang menelaah semua undang-undang dan regulasi yang berkaitan dengan diskursus perlindungan hak kekayaan Intelektual.

2 Peter Mahmud Marzuki, Penelitian Hukum, Jakarta: Kencana Prenada Media Group, 2011, hlm, 24 
2) Pendekatan Perbandingan (comparative approach), yaitu membandingkan salah satu lembaga hukum (legal institutions) dari sistem hukum yang satu dengan lembaga hukum (yang kurang lebih sama dari sistem hukum) yang lain.

3) Pendekatan Historis (historical approach), yakni pendekatan yang dilakukan dengan cara mengkaji dan memahami filosofi dari aturan hukum dari waktu ke waktu terkait dengan perlindungan hak kekayaan intelektual.

\section{Lokasi Penelitian}

Penelitian ini akan dilaksanakan di Kota Baubau Provinsi Sulawesi Tenggara. Adapun lokasi penelitian yang menjadi tujuan penelitian adalah sebagai berikut:

1. Pemerintah Daerah melalui SKPD terkait yaitu Dinas Perindustrian dan Perdagangan Kota Baubau, Dinas Koperasi dan UKM Kota Baubau, Dinas Pendidikan dan Kebudayaan Kota Baubau

2. Kelompok UMKM di bidang kerajinan tangan yang ada di Kota Baubau.

\section{Jenis dan Sumber Data}

\section{Data Primer}

Data primer diperoleh dari studi yang dilakukan langsung di lapangan, sumber data primer pada penelitian ini adalah pemerintah daerah melalui SKPD terkait yaitu Dinas Perindustrian dan Perdagangan Kota Baubau, Dinas Koperasi dan UKM Kota Baubau, Dinas Pendidikan dan Kebudayaan Kota Baubau serta kelompok UMKM di bidang kerajinan tangan yang ada di Kota Baubau yang berkaitan dengan perlindungan hukum hak kekayaan intelektual masyarakat Kota Baubau.

\section{Data Sekunder}

Data sekunder yang utama adalah buku teks karena buku teks berisi mengenai prinsipprinsip dasar ilmu hukum dan pandangan-pandangan klasik para sarjana yang mempunyai kualifikasi tinggi ${ }^{3}$. Dalam penelitian ini bahan hukum sekunder meliputi :
a. Buku-buku ilmiah dibidang hukum;
b. Makalah-makalah;
c. Jurnal ilmiah;

3 Ibid, hlm. 142. 
d. Artikel ilmiah.

\section{Data Tersier}

Data tersier adalah data yang memberikan petunjuk maupun penjelasan terhadap data primer dan sekunder. Dalam penelitian ini data tersier yang digunakan meliputi :

a. Kamus besar bahasa Indonesia;

b. Kamus hukum;

c. Situs internet.

\section{Teknik Pengumpulan Data}

\section{Studi Dokumen atau Bahan Pustaka}

Kegiatan ini ditujukan untuk memperoleh data melalui penelusuran catatan-catatan, tulisan-tulisan atau dokumen-dokumen yang sudah dibuat oleh orang lain yang berhubungan dengan masalah yang dibahas.

\section{Studi Lapangan}

Observasi lapangan dengan pihak-pihak yang berkompeten yaitu pemerintah daerah melalui SKPD terkait yaitu Dinas Perindustrian dan Perdagangan Kota Baubau, Dinas Koperasi dan UKM Kota Baubau, Dinas Pendidikan dan Kebudayaan Kota Baubau serta kelompok UMKM di bidang kerajinan tangan yang ada di Kota Baubau guna memperoleh keterangan data tentang subyek dan objek yang diteliti.

\section{Analisis Data}

Analisis data yang digunakan dalam penelitian ini adalah deskriptif kualitatif yaitu menganalisis dengan menguraikan gejala atau fenomena dan fakta-fakta yang didapat dari lapangan secara obyektif untuk menjawab permasalahan dalam penelitian ini yaitu perlindungan hukum hak kekayaan intelektual masyarakat di Kota Baubau.

\section{ANALISIS DAN PEMBAHASAN}

\section{Potensi Hak Kekayaan Intelektual Masyarakat Kota Baubau}

Berdasarkan data Dinas Koperasi dan Usaha Kecil Menengah (UKM) Kota Baubau tahun 2017, terdapat 4990 Usaha Mikro, 3052 Usaha Kecil dan 280 Usaha Menengah yang 
masing-masing terdiri dari 7 jenis usaha yaitu kuliner, fashion, otomotif, pendidikan, agrobisnis, teknologi internet dan bidang lainnya.

Selain itu, dalam bidang kebudayaan daerah Kota Baubau terdapat beberapa kesenian daerah seperti musik, tari, kerajinan tangan khas daerah dan lain sebagainya yang masih tetap eksis di masyarakat. Hal ini membuktikan bahwa UMKM dan kesenian daerah Kota Baubau mampu hidup dan berkembang dalam menghadapi era perdagangan bebas dan modernisasi yang terjadi saat ini.

Wilayah Kota Baubau merupakan daerah yang sangat kental dengan kehidupan tradisionalnya. Beberapa komoditi tradisional yang kemudian dikembangkan secara turun temurun dan menunjukkan karakteristik daerah yang masih bertahan di tengah era modernisasi saat ini.

Wilayah Kota Baubau memiliki beberapa jenis industri dan kesenian daerah Kota Baubau. Berdasarkan hasil penelitian lapangan dan studi dokumentasi terhadap jenis industri dan kesenian daerah Kota Baubau serta perlindungan hak kekayaan intelektual dapat disajikan dalam tabel berikut:

Tabel. 1 Jenis Industri Masyarakat Kota Baubau dan Perlindungan HKI

\begin{tabular}{|c|c|c|c|c|}
\hline No. & Jenis Industri & Lokasi & $\begin{array}{c}\text { Perlindungan } \\
\text { HKI }\end{array}$ & $\begin{array}{c}\text { HKI yang bisa } \\
\text { Dilindungi }\end{array}$ \\
\hline 1 & Industri Tenunan & $\begin{array}{l}\text { Kampung Sambali (Baadia- } \\
\text { Sambali) dan Sulaa } \\
\text { (Labalawa-Sulaa) }\end{array}$ & Belum ada & $\begin{array}{l}\text { Hak Cipta (Motif } \\
\text { Tenunan) }\end{array}$ \\
\hline 2 & $\begin{array}{l}\text { Industri Anyaman dari } \\
\text { Nentu }\end{array}$ & Kel. Gonda Baru & Belum ada & $\begin{array}{l}\text { Hak Paten dan Desain } \\
\text { Industri }\end{array}$ \\
\hline 3 & $\begin{array}{l}\text { Industri Anyaman dari } \\
\text { Rotan }\end{array}$ & Bugi/Sorawolio & Belum ada & $\begin{array}{l}\text { Hak Paten dan Desain } \\
\text { Industri }\end{array}$ \\
\hline 4 & Industri Daur Ulang & Sukanayo & Belum ada & Desain Industri \\
\hline 5 & Industri Batok Kelapa & Kel. Badia & Belum ada & Desain Industri \\
\hline 6 & Industri Lampu Hias & Kel. Badia & Belum ada & Desain Industri \\
\hline 7 & $\begin{array}{l}\text { Industri Miniatur Khas } \\
\text { Daerah Kota Baubau }\end{array}$ & & Belum ada & Desain Industri \\
\hline 8 & $\begin{array}{l}\text { Industri Jambu Mete } \\
\text { (San Jabil) }\end{array}$ & H. Sahrul & Belum ada & Hak Merek \\
\hline 9 & $\begin{array}{l}\text { Industri Abon Ikan } \\
\text { Tuna (Wolio Snack) }\end{array}$ & Asdin & Belum ada & $\begin{array}{c}\text { Hak Merek dan Rahasia } \\
\text { Dagang }\end{array}$ \\
\hline 10 & Pengrajin Kuningan & Lamangga & Belum ada & Desain Industri \\
\hline 11 & $\begin{array}{l}\text { Pengrajin Perak (Pande } \\
\text { Salaka) }\end{array}$ & Peropa Benteng Keraton & Belum ada & Desain Industri \\
\hline 13 & $\begin{array}{l}\text { Kuliner Khas Kota } \\
\text { Baubau }\end{array}$ & & Belum ada & $\begin{array}{c}\text { Merek } \\
\text { Rahasia Dagang }\end{array}$ \\
\hline 14 & Industri Kelapa Goreng & Wameo & Belum ada & Merek \\
\hline
\end{tabular}




\begin{tabular}{|c|c|c|c|c|}
\hline 15 & $\begin{array}{l}\text { Industri Ikan Panggang } \\
\text { dan Pengasapan Ikan } \\
\text { (Kaholeo) }\end{array}$ & $\begin{array}{l}\text { Kelurahan Nganganaumala, } \\
\text { Kelurahan Waruruma, }\end{array}$ & Belum ada & Merek \\
\hline 16 & $\begin{array}{l}\text { Industri Kerupuk dan } \\
\text { sejenisnya }\end{array}$ & $\begin{array}{l}\text { Kel. Kampeonaho, } \\
\text { Kel. Ngkari-ngkari, Kel. } \\
\text { Nganganaumala }\end{array}$ & Belum ada & Merek \\
\hline 17 & $\begin{array}{l}\text { Industri Gerabah } \\
\text { (Pande Reo) }\end{array}$ & Lipu-Katobengke & Belum ada & Paten dan Desain Industri \\
\hline 18 & Industri Garam & Bonebone & Belum ada & Merek \\
\hline 19 & $\begin{array}{l}\text { Kerajinan Kerang- } \\
\text { Kerangan }\end{array}$ & KEL. SULAA & Belum ada & Desain Industri \\
\hline 20 & $\begin{array}{l}\text { Industri Jipang } \\
\text { (Rangginang) }\end{array}$ & Sorawolio & Belum ada & Merek \\
\hline 21 & $\begin{array}{l}\text { Pengrajin Besi (Pande } \\
\text { Besi) }\end{array}$ & Baadia & Belum ada & Desain Industri \\
\hline 22 & Pengrajin Ukir Kayu & Kel. Ngkari-Ngkari & Belum ada & $\begin{array}{l}\text { Hak Cipta dan Desain } \\
\text { Industri }\end{array}$ \\
\hline 23 & $\begin{array}{l}\text { Industri Gedokan } \\
\text { (Pande Tanu) }\end{array}$ & Waruruma & Belum ada & Paten \\
\hline 24 & $\begin{array}{l}\text { Industri Pengolahan } \\
\text { Mutiara }\end{array}$ & Kel. Palabusa & Belum ada & Desain Industri \\
\hline 25 & $\begin{array}{l}\text { Industri Pembuat } \\
\text { Akuarium }\end{array}$ & Kel. Kadolomoko & Belum ada & Paten dan Desain Industri \\
\hline 26 & $\begin{array}{l}\text { Industri Kerajinan Pot } \\
\text { Bunga }\end{array}$ & Kel. Kadolomoko & Belum ada & $\begin{array}{l}\text { Hak Cipta dan Desain } \\
\text { Industri }\end{array}$ \\
\hline 27 & $\begin{array}{l}\text { Industri Kerajinan } \\
\text { Tudung Saji (Pande } \\
\text { Panamba) }\end{array}$ & Kel. Labalawa & Belum ada & $\begin{array}{l}\text { Hak Cipta dan Desain } \\
\text { Industri }\end{array}$ \\
\hline
\end{tabular}

Tabel. 2 Jenis Kesenian Daerah Kota Baubau dan Perlindungan HKI

\begin{tabular}{|c|c|c|c|c|}
\hline No. & Jenis Kesenian & Nama Kesenian & $\begin{array}{c}\text { Perlindungan } \\
\text { HKI }\end{array}$ & $\begin{array}{l}\text { HKI yang bisa } \\
\text { dilindungi }\end{array}$ \\
\hline 1 & Tari & $\begin{array}{l}\text { Tari Galangi } \\
\text { Tari Mangaru } \\
\text { Tari Linda } \\
\text { Tari Kalegoa } \\
\text { Tari Katiba } \\
\text { Tari Lawati } \\
\text { Tari Honari }\end{array}$ & Belum ada & Hak Cipta \\
\hline 2 & Cerita Rakyat & $\begin{array}{l}\text { Wandiu-diu } \\
\text { Pelanduk dan Harimau } \\
\text { Landoke-ndoke dan } \\
\text { Lakolokolopua } \\
\text { Randasitangi dan Wairiwondu } \\
\text { Lowu-Lowu Marikana } \\
\text { Mengapa Kelapa Bermata } \\
\text { Ubi Karea-rea } \\
\text { Bangun Hijau dan Bangun Merah } \\
\text { Putri Satarina }\end{array}$ & Belum ada & Hak Cipta \\
\hline 3 & Musik dan Lagu & $\begin{array}{l}\text { Gambusu } \\
\text { Gandana Maludu }\end{array}$ & Belum ada & Hak Cipta \\
\hline
\end{tabular}




\begin{tabular}{ll}
\hline Ritual Adat & Pekande-kandea \\
& Posuo \\
& Pekandeana-anana Maelu \\
& Dole-dole \\
& Goraana Oputa \\
& Kunua \\
& Mata'a \\
\hline
\end{tabular}

Berdasarkan Tabel tersebut di atas dapat dideskripsikan bahwa UMKM dan kesenian daerah memberikan kontribusi dalam pembangunan ekonomi daerah, namun demikian UMKM dan kesenian daerah apabila ditinjau dari sisi perlindungan hak kekayaan intelektual masih sangat rendah hal ini dibuktikan dengan belum adanya satu jenis pun UMKM dan kesenian daerah Kota Baubau yang belu terdaftar HKI-nya.

Kondisi tersebut tentu saja miris, mengingat saat ini memasuki era liberalisasi dibidang perdagangan, dimana terhadap setiap karya harus dihargai dalam hal hak ekonominya. Dalam menghadapi persaingan yang semakin ketat akibat semakin terbukanya pasar di dalam negeri, merupakan ancaman bagi UMKM dan kesenian daerah Kota Baubau dengan semakin banyaknya barang dan jasa yang masuk sebagai akibat globalisasi. Oleh karena itu, pembinaan dan pengembangan saat ini dirasakan semakin mendesak dan sangat strategis untuk mengangkat perekonomian rakyat, maka kemandirian dapat terwujud dan tercapai dimasa yang akan datang. Berkembangnya perekonomian rakyat diharapkan dapat meningkatkan pendapatan masyarakat, membuka kesempatan kerja dan memakmurkan masyarakat secara keseluruhan.

Perolehan hak kekayaan intelektual berbanding lurus dengan kesejahteraan atau peningkatan perekonomian pelaku UMKM di satu sisi dan Pemerintah daerah di sisi lain. Dengan pengertian lain, adanya perlindungan HKI pada akhirnya akan mendatangkan pendapatan yang berlebih bagi pelaku UMKM sendiri dan pada gilirannya akan berimbas pada pendapatan daerah yang meningkat dari sektor usaha mikro kecil dan menengah.

Globalisasi akan membawa pengaruh buruk apabila para pelaku usaha belum siap untuk bersaing dalam kancah internasional. Globalisasi dengan rezim liberalisasi mengakibatkan masyarakat yang menghasilkan komoditi tradisional harus mendaftarkan HKI apabila akan bersaing di era liberalisasi ini. Globalisasi dan liberalisasi memang tidak perlu ditolak karena pemerintah sudah menandatangani banyak perjanjian internasional dalam kerangka AFTA atau WTO. Dampak buruk dari globalisasi dan liberalisasi hendaknya dapat diminimalisasi dengan kebijakan-kebijakan strategis yang berpihak 
kepada masyarakat Kota Baubau. Jangan sampai hal ini dibiarkan berjalan sendiri tanpa peningkatan daya saing dan promosi yang memadai.

\section{Faktor-faktor Yang Menghambat Perlindungan Hak Kekayaan Intelektual Masyarakat Kota Baubau}

Hukum dibuat untuk dilaksanakan. Oleh karena itu, tidaklah mengherankan apabila P. Scholten mengatakan bahwa "manakala hukum tidak pernah dilaksanakan, maka tidak lagi disebut sebagai hukum". ${ }^{4}$ Hukum itu sendiri dalam wujudnya sebagai peraturan jelas tidak dapat melakukan semua itu. Dengan demikian menjadi relevan untuk dibahas mengenai faktor-faktor yang mempengaruhi penegakkan hukum.

Faktor-faktor tersebut menurut Soerjono Soekanto adalah sebagai berikut: faktor kaidah hukum/peraturan itu sendiri, faktor petugas/ penegak hukum, faktor sarana atau fasilitas, faktor masyarakat dan faktor budaya. ${ }^{5}$ Pendapat tersebut sejalan dengan yang dikemukakan oleh Lawrent Friedman yang menyatakan bahwa penegakan hukum dipengaruhi oleh tiga hal yaitu substansi hukum (legal subtance), Struktur Hukum (legal structure), budaya hukum (legal culture).

Faktor-faktor tersebut di atas saling berkaitan, karena merupakan esensi dari penegakan hukum serta merupakan tolak ukur dari efektivitas penegakan hukum. Faktorfaktor tersebut apabila dihubungkan dengan perlindungan hukum hak kekayaan intelektual masyarakat Kota Baubau, maka dapat dianalisis sebagai berikut:

\section{Substansi Hukum (Legal Subtance)}

Upaya perlindungan hukum hak kekayaan intelektual dapat dikualifikasikan menjadi upaya hukum represif dan preventif. Upaya hukum preventif tampak pada pengaturan HKI dalam beberapa peraturan perundangan, seperti UU No. 30 Tahun 2000 tentang Rahasia Dagang, UU No. 31 Tahun 2000 tentang Desain Industri, dan UU No. 32 Tahun 2000 tentang Desain Tata Letak Sirkuit Terpadu dan dalam upaya untuk menyelaraskan semua peraturan perundangan di bidang HKI dengan Perjanjian TRIPs, Pemerintah Indonesia mengesahkan UU No.13 Tahun 2016 tentang Paten dan UU No. 20 Tahun 2016 tentang Merek dan Indikasi Geografis. Kedua undang-undang ini menggantikan undang-undang yang lama di bidang terkait serta UU No. 28 tahun 2014 tentang Hak Cipta yang

4 Satjipto Rahardjo, Hukum dan Masyarakat, Bandung: Angkasa, 1986, hlm. 69.

5 Soerjono Soekanto, Faktor-Faktor Yang Mempengaruhi Penegakan Hukum, Jakarta: Rajawali Pers, 2008, hlm. 9. 
menggantikan undang-undang yang lama. Upaya hukum represif tampak pada pengaturan mengenai tindak pidana di dalam ketentuan tersebut di atas.

\section{Struktur Hukum (Legal Structure)}

Setiap penegak hukum secara sosiologis mempunyai kedudukan (status) dan peranan (role). Kedudukan merupakan posisi tertentu di dalam struktur kemasyarakatan. Kedudukan itu merupakan suatu wadah yang isinya hak-hak dan kewajiban-kewajiban tertentu. Hak dan kewajiban itu sendiri merupakan peranan. Oleh karena itu, seseorang yang mempunyai kedudukan tertentu secara sosiologis lazimnya dinamakan pemegang peran (role occupant).

Faktor substansi hukum memang telah memberikan perlindungan hukumnya, akan tetapi rumitnya proses teknis berkaitan dengan pendaftaran untuk memperoleh perlindungan hukum hak kekayaan intelektual sebagaimana diatur dalam undang-undang menjadi salah satu penyebab, sehingga tidak mendaftarkan haknya. Hal ini disebabkan, pendaftaran hak kekayaan intelektual (HKI) harus diajukan ke Direktorat Jenderal Hak Kekayaan Intelektual-Kementerian Hukum dan HAM di Jakarta. Tentu saja hal ini berkaitan dengan fasilitas dan sarana penunjang untuk memperlancar dan mempermudah perolehan perlindungan hukum hak kekayaan intelektual, dimana seyogyanya di setiap Kabupaten/Kota terdapat sarana dan fasilitas untuk mempermudah pendaftaran hak kekayaan intelektual (HKI), seperti tersedianya konsultan hak kekayaan intelektual (HKI) untuk dapat membantu melakukan proses pendaftaran hak kekayaan intelektual (HKI). Selain itu, ketersediaan tenaga penyuluh di Disperindag, Dinas Koperasi dan UKM serta Dinas Pendidikan dan Kebudayaan yang benar-benar memahami teknis penyusunan pendaftaran hak kekayaan intelektual (HKI) juga menjadi solusi yang tepat dalam usaha melindungi hak kekayaan intelektual (HKI) masyarakat. ${ }^{6}$

Berdasarkan penjelasan tersebut, faktor penegak hukum, apabila dihubungkan dengan perlindungan hukum hak kekayaan intelektual (HKI) maka tampak bahwa peranan dinas masih terbatas pada peranan pasif dalam pemberdayaan, seperti kegiatan-kegiatan penyuluhan dan pelatihan. Dinas terkait relatif belum memiliki pemahaman mengenai teknis penyusunan permohonan pendaftaran hak kekayaan intelektual (HKI).

\footnotetext{
Jabalnur menguraikan proses pendaftaran hak paten atau HAKI berdasarkan peraturan perundangundangan yang berlaku di Indonesia. Hal ini dilakukan di dalam rangka memberikan perlindungan hukum terhadap temuan hasil karya cipta putra putri Indonesia. Terkait dengan hal ini, periksa Jabalnur, Op.Cit., hlm. 278-290.
} 
Selain masalah penegakan hukum juga terkait dengan masalah sarana atau fasilitas terkait dengan efektivitas dari sanksi negatif yang diancamkan terhadap peristiwaperistiwa tertentu. Tujuan dari adanya sanksi-sanksi tersebut adalah agar dapat mempunyai efek menakutkan terhadap orang-orang yang melakukan pelanggaran, akan tetapi apabila ancaman hukuman hanya tercantum di atas kertas, maka hal itu tidak ada artinya. Efek dari suatu sanksi negatif tersebut akan datang dari kekuatan suatu ancaman yang benar-benar diterapkan, apabila suatu ketentuan dilanggar. Dengan demikian, yang penting pada sanksi negatif adalah kepastian bahwa sanksi tersebut akan diterapkan. ${ }^{7}$

Faktor ini apabila hal ini dihubungkan dengan perlindungan hukum HKI masyarakat Kota Baubau, maka tampak bahwa sarana dan fasilitas pendukung perlindungan hukum HKI relatif belum memadai. Hal ini disebabkan, proses pendaftaran masih harus diajukan ke Jakarta (Direktorat Jenderal Hak Kekayaan Intelektual). Hal ini tentu saja menghambat masyarakat yang akan mendaftarkan perlindungan HKI, karena dihadapkan pada lokasi atau jarak yang jauh. Ketersediaan sumber daya manusia yang memahami teknis penyusunan permohonan pendaftaran HKI menjadi permasalahan serius, mengingat teknis penyusunan permohonan membutuhkan kecermatan, apabila hal ini dibiarkan, maka akan mengakibatkan proses pendaftaran HKI memakan waktu yang lama, karena apabila dalam permohonan terdapat kesalahan atau kekurangan, maka permohonan tersebut akan dikembalikan untuk diperbaiki. Padahal apabila masyarakat memperoleh HKI, pada gilirannya akan menambah pendapatan daerah, dengan asumsi bahwa kegiatan perekonomian masyarakat meningkat.

\section{Budaya Hukum (Legal Culture)}

Penegakkan hukum berkaitan erat dengan faktor bekerjanya hukum. Tata hukum merupakan seperangkat norma yang menunjukkan apa yang harus dilakukan atau apa yang harus terjadi. Bekerjanya hukum merupakan suatu pranata dalam masyarakat, maka perlu memasukkan satu faktor yang menjadi perantara yang memungkinkan hukum itu melakukan regenerasi atau memungkinkan terjadinya penerapan dari norma hukum itu. Regenerasi atau penerapan hukum hanya dapat terjadi melalui manusia sebagai perantaranya. Masuknya manusia dalam pembicaraan mengenai hukum, khususnya di dalam hubungan dengan bekerjanya hukum itu, akan membawa penglihatan mengenai

\footnotetext{
7 Soerjono Soekanto, Efektivitas Hukum dan Peranan Sanksi, Bandung: Remaja Karya, 1985, hlm. 90-91.
} 
hukum sebagai karya manusia di dalam masyarakat, sehingga faktor-faktor yang memberikan beban pengaruh (impact) terhadap hukum tidak dapat dibatasi. ${ }^{8}$

Perolehan HKI, khususnya yang berkaitan dengan produk masyarakat yaitu hak merek dan hak paten, harus melalui proses pendaftaran berbeda dengan hak cipta cukup dengan diumumkan saja sudah mendapat perlindungan hukum. Dalam proses pendaftaran sendiri terdapat berkas-berkas yang harus dipenuhi. Faktanya adalah masih sedikit masyarakat yang memahami kelengkapan pendaftaran yang harus dipenuhi. Selain itu, biaya yang relatif mahal untuk mendapatkan HKI juga menjadi penyebab masyarakat enggan untuk melakukan pendaftaran HKI. Penjelasan tersebut semakin menegaskan, bahwa ketersediaan sumber daya manusia yang memahami teknis penyusunan permohonan pendaftaran HKI menjadi suatu hal yang penting. Sosialisasi yang dilakukan akan lebih mengena apabila materi disampaikan oleh orang yang benar-benar memahami teknis penyusunan permohonan pendaftaran $\mathrm{HKI}$.

Selain itu, budaya komunal sangatlah kental di masyarakat khususnya di Kota Baubau yang merupakan salah satu wilayah kesultanan Buton yang memiliki banyak budaya kesenian daerah. Seperti yang terjadi di Bali, Masyarakatnya cenderung senang apabila proses maupun produknya ditiru oleh pihak lain, karena hal ini mendatangkan suatu kebahagiaan tersendiri bagi si penciptanya. Tentu saja budaya semacam ini sangat menghambat penegakkan perlindungan hukum HKI di era liberalisasi saat ini. Hal ini tentu saja menjadi suatu tantangan sendiri bagi pemerintah, khususnya ditingkatkan pemerintah daerah, karena mengubah paradigma seperti itu tidaklah semudah membalikkan telapak tangan.

\section{Model Pengembangan Perlindungan Hukum Hak Kekayaan Intelektual Masyarakat}

\section{Kota Baubau}

Membicarakan industri kreatif sangat berhubungan erat dengan perlindungan hak kekayaan intelektual (HKI). Betapa tidak, dalam industri kreatif sendiri sangat syarat dengan kreativitas dan inovasi. Kreativitas dan inovasi ini dikenal dengan kekayaan intelektual. Mengingat dalam industri kreatif syarat dengan kekayaan intelektual, maka menjadi absolut jika kekayaan intelektual yang dimiliki industri kreatif sebelum dieksploitasi mendapatkan perlindungan dari segi hukum terlebih dahulu. Selain industri

8 Satjipto Rahardjo, Hukum dan Masyarakat, Op.cit., hlm. 48. 
kreatif, budaya daerah juga mempunyai hubungan erat dengan perlindungan hak kekayaan intelektual terhadap hak komunal.

Sistem perlindungan kekayaan intelektual di daerah tampaknya belum berpihak bagi tumbuh dan berkembangnya industri kreatif dan kebudayaan daerah. Persoalan ini seyogianya benar-benar menjadi pusat kepedulian dan perhatian bagi pemerintah daerah. Kepedulian dan perhatian ini tidak sekedar diekspresikan melalui pernyataan-pernyataan di publik, melainkan harus diimbangi dengan adanya action yang nyata dalam upaya memperbaiki sistem perlindungan kekayaan intelektual di daerah. Pemerintah hendaknya segera mengambil langkah-langkah strategis untuk hal tersebut.

Bentuk langkah strategis yang segera harus ditindaklanjuti oleh pemerintah daerah adalah adanya upaya penataan atas kelembagaan yang menjalankan tugas melakukan perlindungan atas kekayaan intelektual di daerah. Penataan kelembagaan yang dimaksudkan adalah terbentuknya suatu lembaga yang kuat dan mampu menjalankan fungsi perlindungan secara efektif serta terpadu.

Diharapkan lembaga ini kelak menjalankan fungsi edukasi/penyadaran tentang pentingnya mengakui, menghormati dan melindungi kekayaan intelektual milik orang lain. Lembaga ini juga berfungsi menyampaikan keberatan/oposisi atas pendaftaran kekayaan intelektual di Ditjen HKI di mana kekayaan intelektual yang didaftar tersebut sudah dimiliki oleh salah satu masyarakat di daerah serta menjalankan fungsi mengadvokasi pelanggaran kekayaan intelektual milik masyarakat di daerahnya. Selain itu berfungsi memfasilitasi pemanfaatan kekayaan intelektual milik masyarakat di daerah.

Dengan terbentuknya lembaga yang memiliki fungsi di atas, maka ada dua hal yang dapat diharapkan. Pertama, eksis dan survive-nya industri kreatif dan kebudayaan daerah. Industri kreatif pada dasarnya industri yang digerakkan karena adanya kreativitas dan inovasi atas produk mereka. Dengan landasan kreativitas dan inovasi, pelaku usaha mampu eksis dan survive. Perlindungan kekayaan intelektual yang digerakkan oleh lembaga perlindungan kekayaan intelektual di daerah sangat mendukung tumbuhnya kreativitas dan inovasi. Maka, sudah dapat dipastikan industri kreatif akan mampu bertahan hidup.

Selain itu, dapat meminimalisasi pelanggaran kekayaan intelektual yang ada di lingkungan industri kreatif dan kebudayaan daerah. Dengan adanya lembaga perlindungan kekayaan intelektual di daerah yang kuat dan tidak birokratis, maka diharapkan dapat memantau setiap bentuk pelanggaran atas kekayaan intelektual yang 
dimiliki oleh pelaku industri kreatif dan budaya daerah. Dengan adanya pemantauan dan dilanjutkan dengan advokasi bila terjadi pelanggaran, maka pelanggaran kekayaan intelektual dapat diminimalisasi. Inilah kiranya tentang gagasan perlindungan kekayaan intelektual yang pro industri kreatif dan budaya daerah.

Hak kekayaan intelektual menjadi sangat penting untuk mendukung pembangunan ekonomi, karena unsur teknologi, industri, dan budaya adalah unsur vital dalam aktivitas ekonomi negara secara umum dan terkhusus bagi daerah Kota Baubau. Dalam rangka menyinergikan pelaksanaan sistem hak kekayaan intelektual di Kota Baubau dengan pelaksanaan pembangunan ekonomi daerah, maka diperlukan model perlindungan hukum hak kekayaan intelektual masyarakat Kota Baubau agar dapat meletakkan dasar baru bagi pengelolaan hak kekayaan intelektual melalui pemanfaatan ekonomis yang kontribusinya bagi pembangunan daerah Kota Baubau lebih nyata.

Menurut peneliti, model pengembangan perlindungan hukum hak kekayaan intelektual masyarakat Kota Baubau adalah sebagai berikut:

\section{Pembentukan peraturan daerah mengenai perlindungan hak kekayaan intelektual masyarakat Kota Baubau}

Pembentukan peraturan daerah sebagai salah satu perangkat yang dapat digunakan dalam melindungi hak kekayaan intelektual masyarakat Kota Baubau. Gagasan pembentukan peraturan daerah yang mengatur mengenai perlindungan hak kekayaan intelektual masyarakat harus dibuat sesuai dengan kondisi dan kebutuhan masyarakat lokal. Mengingat bahwa budaya masyarakat Indonesia berbeda dengan budaya luar termasuk di dalam adalah budaya masyarakat Kota Baubau.

Sebagaimana yang diungkapkan oleh Agus Sardjono, bahwa pemerintah dapat mempertimbangkan penyusunan perundang-undangan sui generis yang di dalamnya mengatur mengenai masalah akses orang asing terhadap sumber daya hayati dan pengetahuan tradisional yang terkait, serta pembagian manfaat yang terjadi karena akses tersebut. Aspek budaya yang masuk dalam hak kekayaan komunal milik masyarakat tradisional perlu juga diakomodasi dalam peraturan daerah.

\section{Pendokumentasian terhadap kekayaan intelektual Masyarakat Kota Baubau}

Pendokumentasian bertujuan untuk mengklaim jenis-jenis hak komunal dan hak personal di setiap daerah, menangkal pendaftaran hak komunal dan hak personal yang dilakukan oleh orang asing dan pihak-pihak yang tidak bertanggung jawab serta menyebarluaskan 
kemanfaatan hak kekayaan intelektual kepada masyarakat Kota Baubau. Dalam pelaksanaan pendokumentasian ini bukan berarti tidak mengalami kendala. Akan tetapi kendala tersebut perlu ada solusi yang nyata yaitu dengan mengajak para stakeholders atau pemangku kepentingan untuk berkomitmen penuh, melakukan digitalisasi data dan membuat akses informasi melalui Internet.

\section{Peran aktif dan komitmen dari para pemangku kepentingan untuk melindungi kekayaan intelektual Masyarakat}

Dalam menyelesaikan permasalahan HKI ini perlu adanya peran aktif dari para pemangku kepentingan. Komitmen bersama para pemangku kepentingan menjadi modal dasar dalam perubahan rezim HKI yang sesuai dengan kondisi di Kota Baubau. Dalam buku yang ditulis oleh Sudarmanto, beliau membagi para pemangku kepentingan menjadi 4 (empat) yaitu pelaku, pelatih, promotor dan wasit. Keempat kelompok pemangku kepentingan tersebut harus bersinergi dengan baik untuk dapat melindungi kekayaan intelektual yang ada di Indonesia. Yang dimaksud dengan pelaku adalah pendesain, penemu, pencipta, pemohon HKI, pengrajin, masyarakat industri, pelaksana HKI, dan lain-lain. Pelatih adalah kementerian, non kementerian, dinas, pemda terkait, perguruan tinggi dan Lembaga Penelitian, konsultan HKI, dan lain sebagainya. Promotor terdiri dari asosiasi (kerajinan, industri dan perdagangan), Kadin, pengusaha/inventor, LSM, dan lain sebagainya. Sedangkan wasitnya adalah kantor HKI, pengadilan, mahkamah agung, polisi, dan jaksa. ${ }^{9}$

\section{Membangun budaya hukum bagi masyarakat}

Membangun budaya hukum bagi masyarakat merupakan salah satu cara untuk dapat memberikan kesadaran bagi masyarakat akan pentingnya HKI di era pasar bebas mendatang. Friedman mengatakan bahwa budaya hukum (legal culture) adalah unsur yang utama dapatnya suatu sistem hukum berjalan. Yang dimaksud dengan budaya hukum adalah persepsi masyarakat terhadap hukum dan sistem hukum, pandangan, nilai, ide dan pengharapan-pengharapan mereka terhadap hukum. Perlu adanya sosialisasi dalam bidang HKI yang dilakukan secara menyeluruh di berbagai kalangan agar terdapat pemahaman akan HKI dan tidak terjadi kesenjangan pemahaman antara pemerintah daerah dengan masyarakat.

9 Sudarmanto, KI dan HKI Serta Implementasinya Bagi Indonesia, Jakarta: PT. Elex Media Komputindo, 2012, hlm. 113 


\section{Pelatihan Pendaftaran dan pencatatan HKI}

Salah satu kendala dalam memperoleh hak kekayaan intelektual adalah ketidaktahuan para penemu/pengrajin, atau pencipta atas proses pencatatan atau pendaftaran untuk mendapatkan hak di Dirjen HKI. Oleh karena itu, pemerintah harus mengambil inisiatif untuk memberikan pengetahuan tentang pencatatan atau pendaftaran HKI melalui pelatihan- pelatihan pendaftaran dan pendaftaran HKI dengan melibatkan pihak- pihak terkait seperti Perguruan Tinggi, Sentra HKI, LBH dan lain- lain.

\section{KESIMPULAN}

1. Kota Baubau mempunyai potensi yang sangat besar dalam perlindungan HKI karena memiliki keanekaragaman budaya dan hasil- hasil industri kreatif yang mampu hidup dan berkembang dalam menghadapi era perdagangan bebas dan modernisasi yang terjadi saat ini. Namun belum ada yang mendapatkan perlindungan HKI. perlindungan hukum di bidang HKI di Kota Baubau mendapatkan beberapa kendala di antaranya, pertama masih rendahnya tingkat pengetahuan masyarakat bahkan pemerintah tentang hak kekayaan intelektual itu sendiri, mulai dari ruang lingkup, proses pendaftaran, dan manfaat apa yang diperoleh dari adanya perolehan hak dari kekayaan intelektual. Kedua, relatif masih rendahnya insentif atau penghargaan pemerintah atas karya cipta masyarakat hingga pada akhirnya kurang memicu para seniman, peneliti ataupun penemu untuk menghasilkan karya yang inovatif. Ketiga, kurangnya informasi tentang HKI yang disebabkan oleh jauhnya jarak letak tempat penemu/pengrajin terhadap pusat- pusat informasi HKI.

2. Model pengembangan perlindungan Hak kekayaan intelektual masyarakat kota Baubau dapat meliputi:

1) Pembentukan payung hukum berupa perda yang mengatur Hak Kekayaan Intelektual

2) Pendokumentasian HKI masyarakat Kota Baubau

3) Peran aktif pihak terkait/ pemerintah untuk melindungi dan menumbuhkan kesadaran kepada pengrajin/ penemu/ seniman akan pentingnya HKI.

4) Membangun budaya hukum bagi masyarakat melalui seminar- seminar atau lokakarya budaya.

5) Pelatihan pencatatan dan pendaftaran HKI. 


\section{Daftar Pustaka}

\section{Buku}

Badan Penelitian dan Pengembangan HAM Kemenkumham, Perlindungan Kekayaan Intelektual atas Pengetahuan Tradisional dan Ekspresi Budaya Tradisional Masyarakat Adat, Bandung: Alumni, 2013.

Dalimunthe, Chadidjah. Pelaksanaan Landreform di Indonesia dan Permasalahannya, Medan: USU Press, 1998.

Djumhana, Muhamad dan R. Djubaedillah. Hak Milik Intelektual (Sejarah Teori dan Prakteknya di Indonesia). Bandung: Citra Aditya Bakti, 1996.

Komar, Mieke dan Ahmad M. Ramli. "Perlindungan Hak Atas Kepemilikan Intelektual Masa Kini dan Tantangan Menghadapi Era Globalisasi Abad 21", Makalah, Seminar Pengembangan Budaya Menghargai HKI di Indonesia Menghadapi Era Globalisasi Abad 21, Bandung, 28 November 1998.

Marzuki, Peter Mahmud, Penelitian Hukum, Jakarta: Kencana Prenada Media Group, 2011. Mayana, Ranti Fauza. Perlindungan Desain Industri di Indonesia. Jakarta: PT Gramedia Widiasarana Indonesia, 2004.

Rahardjo, Satjipto, Hukum dan Masyarakat, Bandung: Angkasa, 1986.

Riswandi, Budi Agus dan M. Syamsuddin, Hak Kekayaan Intelektual dan Budaya Hukum, Jakarta: PT Raja Grafindo Persada, 2005.

Riswandi, Budi Agus dan Siti Sumartinah, Masalah-Masalah HAKI Kontemporer, Yogyakarta: Gitanagari, 2006.

Sardjono, Agus, Hak Kekayaan Intelektual \& Pengetahuan Tradisional, Bandung: Alumni, 2010.

Soekanto, Soerjono, Efektivitas Hukum dan Peranan Sanksi, Bandung: Remaja Karya, 1985. Faktor-Faktor Yang Mempengaruhi Penegakan Hukum, Jakarta: Rajawali Pers, 2008.

Sudarmanto, KI dan HKI Serta Implementasinya Bagi Indonesia, Jakarta: PT. Elex Media Komputindo, 2012.

\section{Jurnal}

Hartini, Rahayu, "Kajian Implementasi Prinsip-prinsip Perlindungan HaKI dalam Peraturan Per-UU-an HaKI di Indonesia", Humanity, Vol. 1 No. 1, September 2005. 
Jabalnur, "Perlindungan Hak Paten bagi Pengrajin Khas", Halu Oleo Law Review (HOLREV), Vol. 1, Issue 2, September 2017, http://ojs.uho.ac.id/index.php/holrev/article/view/3646/3139, diakses pada tanggal 13 Januari 2018.

Marzuki, Peter Mahmud, "Pemahaman Praktis Mengenai Hak Milik Intelektual", Jurnal Hukum Ekonomi. Edisi III. Surabaya: FH Unair, 1996.

Rahayu, Dewi, "Perlindungan Hukum Terhadap Hak Cipta Motif Batik Tanjungbumi Madura", Mimbar Hukum, Vol. 23 No. 1, Februari 2011, Yogyakarta: FH UGM. 